\title{
INTERDISCIPLINARY ASSESSMENT, ANALYSIS AND DIAGNOSIS OF A HISTORIC TIMBER ROOF STRUCTURE FROM THE 2OTH CENTURY
}

\author{
BOGDAN ISOPESCU ${ }^{1 *}$, ALEXANDRA KELLER ${ }^{1}$, VALERIU STOIAN $^{2}$ AND \\ MARIUS MOSOARCA ${ }^{1}$ \\ ${ }^{1}$ Politehnica University of Timisoara, Faculty of Architecture and Urban Planning \\ 2/A Traian Lalescu, Zip code 300223, Timișoara, Romania \\ e-mail: bogdan.isopescu@upt.ro (*corresponding author) \\ ${ }^{2}$ Faculty of Civil Engineering, Politehnica University of Timișoara (UPT) \\ Traian Lalescu street, nr. 2, 300223, Timisoara, Romania \\ e-mail: valeriu.stoian@upt.ro
}

Keywords: Historical Structure, Timber Truss, Assessment

\begin{abstract}
Historic roof structures are complex systems which cannot be assessed individually but need a more holistic approach, in order to understand them as a whole. The great variety of contexts in which the building and its roof were placed, of architectural styles which ultimately influence the shape of the roof but also the diversity of technical solutions used by the craftsman to respond to these needs and its state of conservation, make a multidisciplinary approach necessary.
\end{abstract}

While 18th and 19th century roof structures from Timisoara, a city from the western part of Romania, proved out to be complex structures which a high value from urban planning, architectural, symbolical and structural point of view, the 20th century is a period of transition with a wide array of influences, mix of styles and technological improvement of the structures.

Therefore, based on the roof structure of the Löffler Palace, built between 1912-1913, placed in the historic centre of the city, the paper tries to highlight that roof structures from this period are also far more than structural systems. Based on a thorough historical analysis and visual inspection of the structure, by using a multidisciplinary assessment procedure [1], the paper shows that 20th century roof structures are closely related to the building they belong, to their context and have a significant philosophical/symbolic and aesthetical value.

At the same time, the procedure also addresses the role of assessment, diagnosis, conservation and maintenance, the structural integrity of the roof, its influence on the seismic behaviour of the historic building, highlighting the connection between the roof, the building and its environment. 


\section{INTRODUCTION}

Due to the complexity of heritage structures the ICOMOS principles are highly recommending a multidisciplinary approach when assessing their value and state of conservation in order to be able to properly develop intervention strategies which could preserve the integrity of the structures without affecting their historical, cultural and aesthetical value [1].

Considering this in recent years various assessment methodologies and procedures have been developed, suitable for the evaluation of historic timber roof structures which are trying to approach them for from various points of view. These methodologies, developed by different research group during COST actions, rather focus on the structural value without also considering the complex way of thinking in which these structures were built and their connection to everything that surrounds them. These methodologies mainly focus on the onsite evaluation of the roof structure and the timber elements $[2,3]$ and their state of conservation, while also addressing the mechanical properties of the timber $[4,5]$ and the static behaviour of the structure [6-8]. The same research groups also focus on monitoring techniques which could lead to a proper understanding of the structural behaviour of the roof structure and therefore ensure the development of coherent maintenance strategies. Only a few studies, try to look further and also include a historical analysis of the building and the roof, or also consider the effect of various environmental factors on the state of conservation of the timber [9-11] or even a geometrical analysis of the structure [12-14].

Studies performed on different roof structures 18 th and 19 th century, philosophical point of Since the city sionificantly doveloped important role in definin inter-disciplinary analysis was aiso performed on
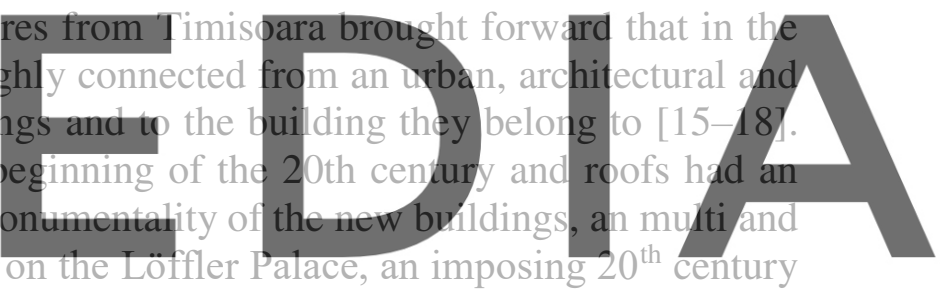
palace which could highlight the importance of also consider urban planning principles,

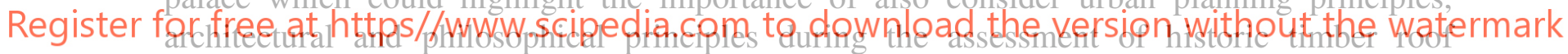
structures.

At the same time, the study is also trying to highight the importance of a thorough preliminary geometric analysis of the roof structures before performing numerical simulations. Therefore it also presents a comparison between the structural behaviour of a truss of the roof structure which is ignoring the cross-section reduction of the timber elements and is considering the joints as hinges, with a model developed considering the on-site observations concerning the decay of the timber elements and their cross-section loss and the semi-rigid behaviour of the timber joints.

\section{INTERDISCIPLINARY ASSESSMENT OF THE ROOF STRUCTURE}

\subsection{Historic context}

Timisoara is the biggest city located in the western region of Romania. Its current built fabric was defined under the Habsburg Empire's rule, most of the previous traces left after Hungarian and Ottoman occupation were removed.

The general guiding principles for the development of the city, by tearing down the 
fortification and connecting the existing districts, were drawn by architect Ludwig von Ybl and engineer Aladar Sebestyen in 1895. A radial scheme was adopted, following the Viennese model, creating a green corridor alongside the Bega Canal, expanding or building new boulevards and creating new public squares. The idea of creating a large new square in front of the Opera, connecting the existing two squares in the north, reflects emphatically the spirit of the bourgeoisie of that time [19]. Several iterations were developed from this initial plan, scaling down and adapting its ambitious and idealistic proposals to the cities economic power.

As seen in Figure 1a, Ludwig von Ybl proposed a long square without obstructing the Huniade Castle, the oldest monument in the city built between 1443-1447. The first side of the square to be developed was the NW starting with the Lloyd building finished in 1912 [20]. The south-eastern side of the square was later developed but never finished in that time, but later on in the 1960's.

The Loffler Palace was built in 1912-1913, the project is assumed to be signed by the architect Henrik Telkes for the grain merchant Leopold Löffler. The building was set in front of the Huniade Castle, thus continuing the square front (Figure 1b,c). The layout and the façades of the building are atypical because of the emphasis put on the northern and southern facades and not the main one towards the square (Figure 2). Also, the back façade towards the castle is treated in a technical fashion, absent of ornaments, with recesses for lighting and ventilation. It somehow suggests that another building should be attached to form a compact block and ignores the proximity to the Castle which makes this unlikely.
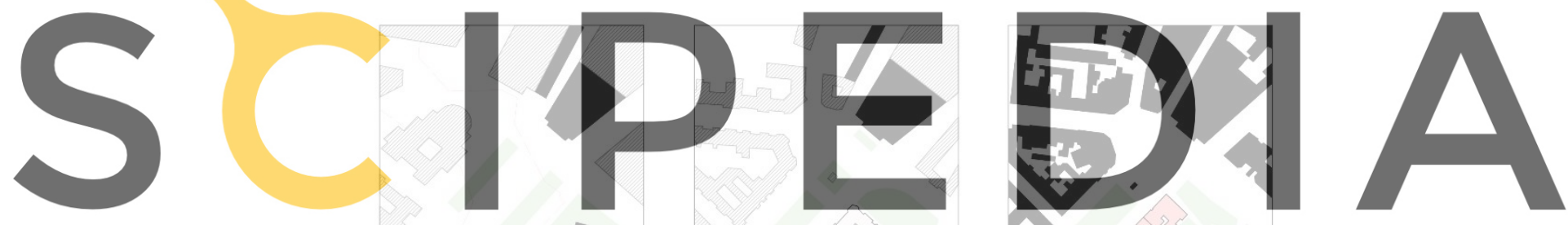

Register for free at https//www.scipedia.com to download the' version without the watermark

a)

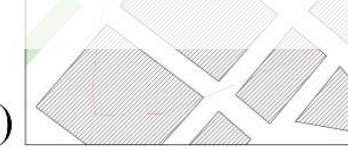

b)

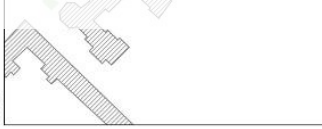

c)

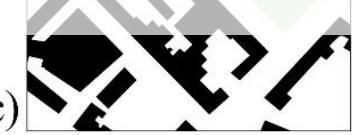

Figure 1: Page layout Evolution diagram of the urban fabric (a) 1895; b) 1913; c)2020)

The building is comprised of an underground floor for storage, a commercial ground floor, three stories of apartments for tenants and loft rooms for technical facilities and storage. The general dimensions of the building are 88 x 29 m. It consists of three distinct parts which function independently each with an interior courtyard. The structural system is quite innovative for the period. The massive brick masonry is mixed with concrete such as beams and columns to obtain larger openings at the ground floor. The slabs above the basement and the ground floor are made of concrete while the others are made of timber. 


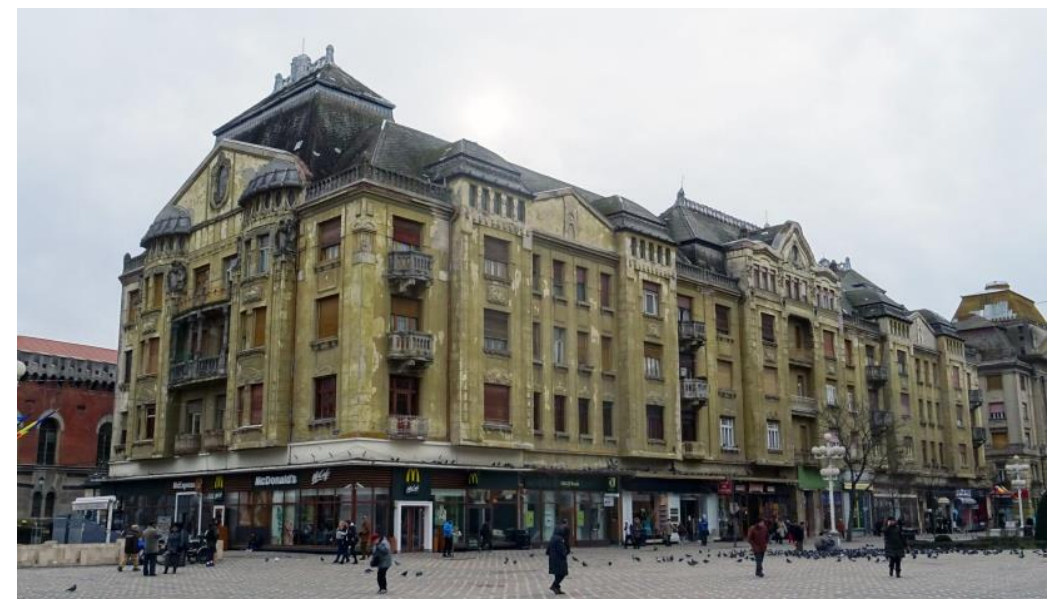

Figure 2: Loffler Palace overview

\subsection{The roof structure}

Architecture also plays a significant role in shaping the roof and the roof structure. The secession style of the building and the adopted urban principles led towards the definition of the tall roof above the gable (Figure 2).

The roof structure has three distinct structural typologies. The first towards the square

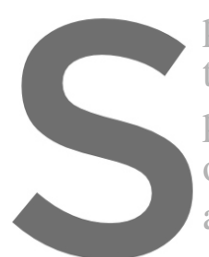
presents a king and queen post the roof. The average span is presents a simplified ver of $6.4 \mathrm{~m}$ and a height of $4.1 \mathrm{~m}$. The unique and sole valuable parts areas towering at the ext and queen post with double compound rafters (Figure 3).

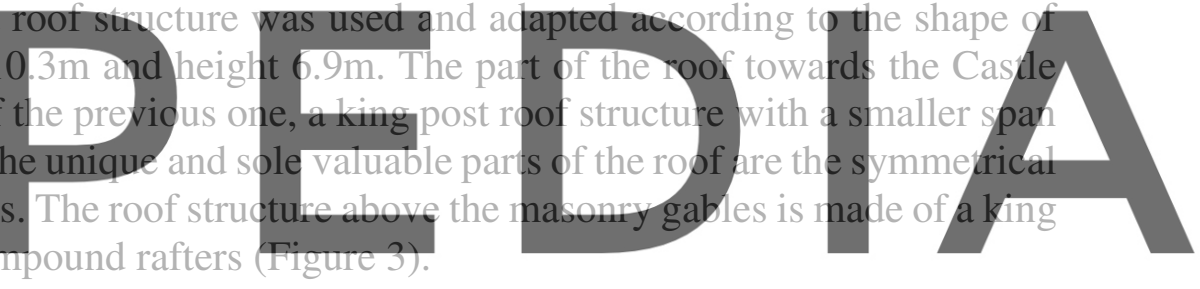

Register for free at https//www.scipedia.com to download the version without the watermark
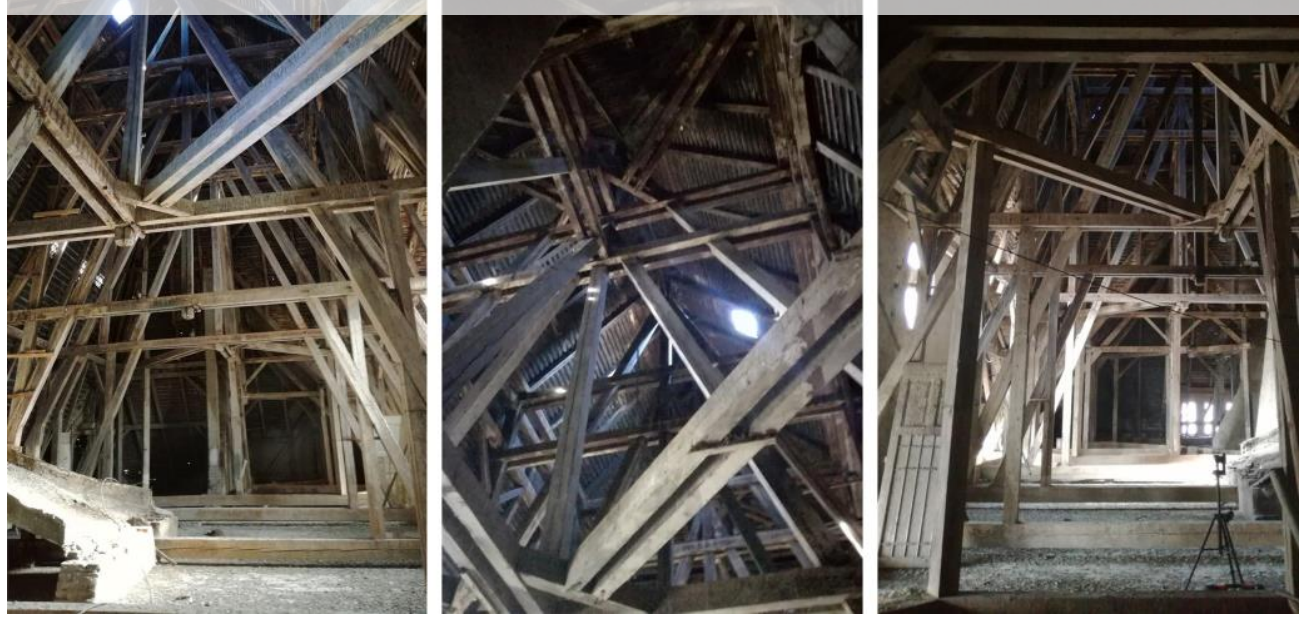

Figure 3: Roof structure above the gables 
The towering roof structure consists of five trusses spanning $10.4 \mathrm{~m}$ and having a height of $12.3 \mathrm{~m}$ (Figure 4). The main trusses are connected through a secondary truss to the gable wall. On each of the lateral parts, there is a half truss positioned perpendicular to the main trusses and one in each corner composing the hips and adding to the overall stiffness of the structure. The half trusses are connected through the king and queen posts and fastened with double collars at the three purlin levels.
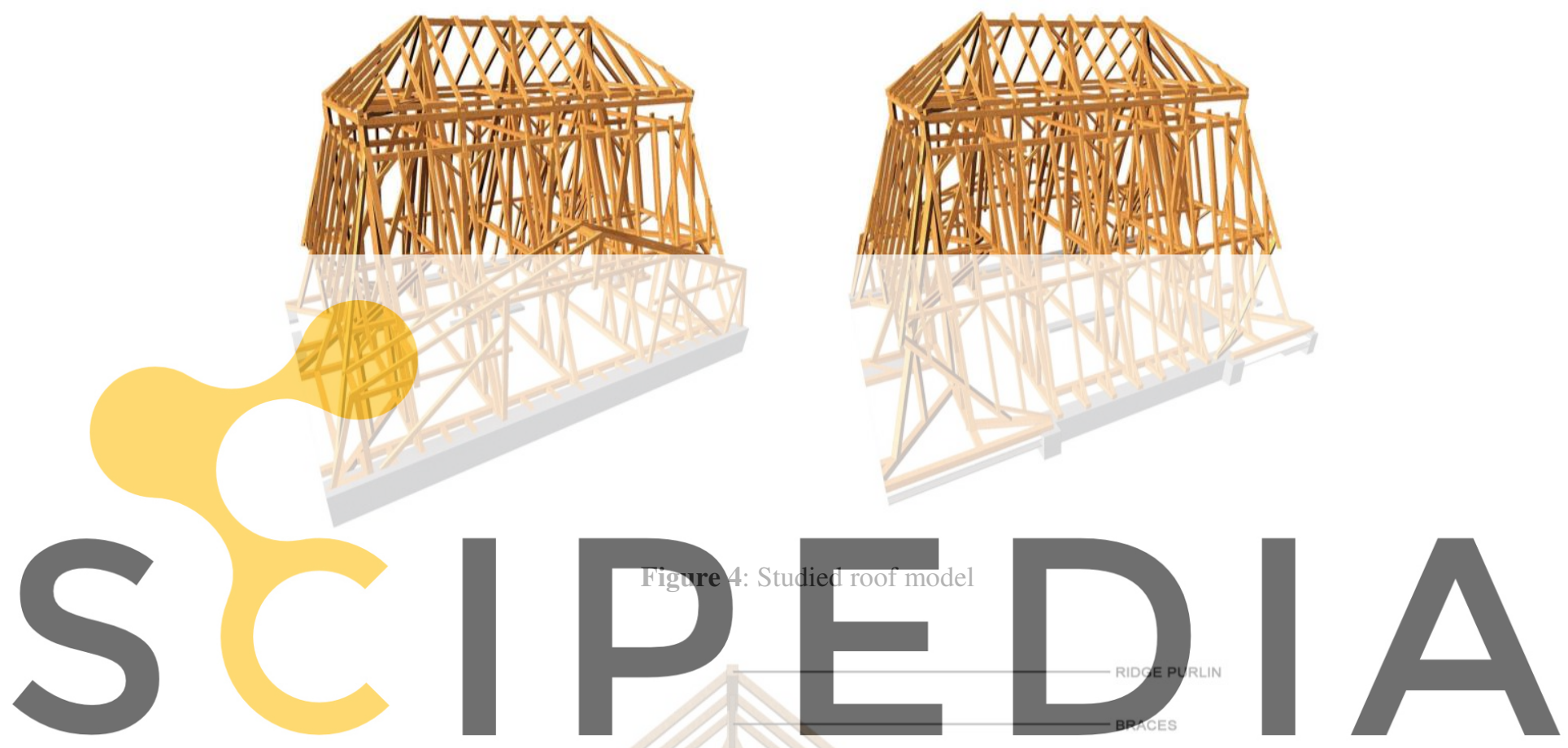

Register for free at https//www.scipedia.com to download the versibutipwithout the watermark

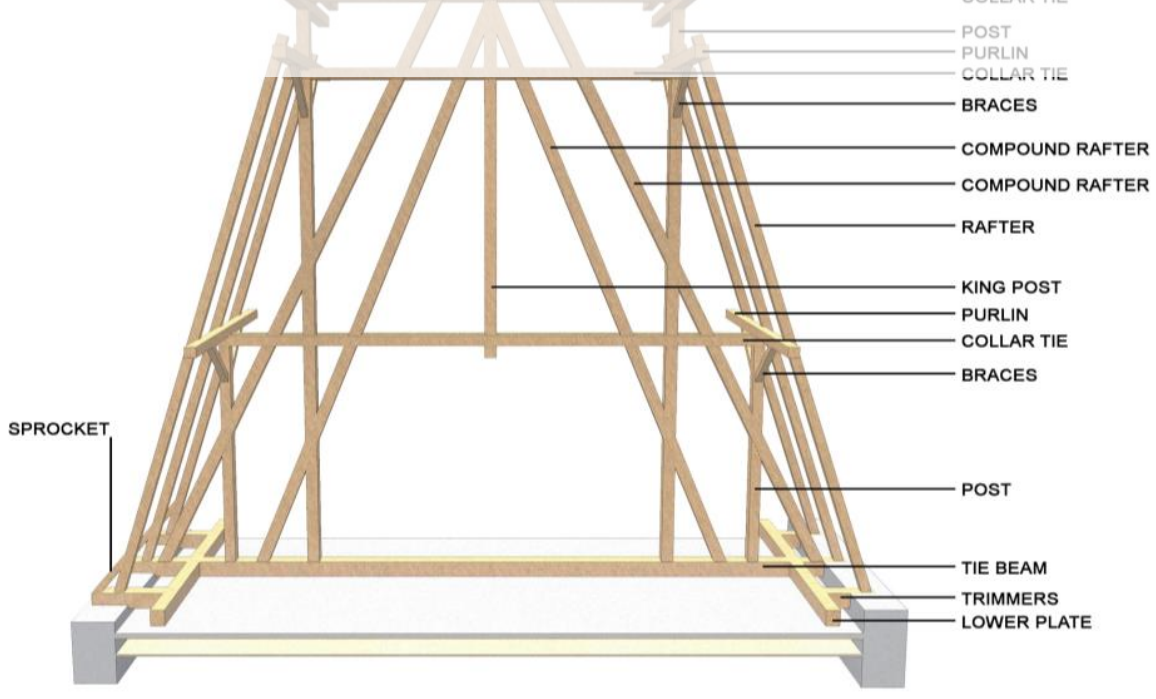

Figure 5: Truss components 
The general dimensions for the timber elements are as follows: tie beams, lower plates and trimmers 250x200mm; king posts, queen tall posts and ridge purlin 180x180mm; queen short posts and purlins $160 \times 160 \mathrm{~mm}$; collars $160 \times 100 \mathrm{~mm}$; rafters $140 \times 100 \mathrm{~mm}$; braces and sprockets $100 \times 100 \mathrm{~mm}$.

The stiffness perpendicular to the trusses is minimally ensured by bracing each of the posts to the corresponding purlins and through the lower plates. The whole tower structure is stiffened at the short ends by half-trusses braced with diagonal lower plates and collar ties. Additionally, in order to increase the rigidity of the structure, all the trusses are connected by eaves and intermediate purlins and an additional system of timber elements, composed of headers and trimmers, placed over the walls. The presence of the gable wall A-frame stiffens and connects the five main central trusses.

There are two types of joints used for the connection of the various wood elements of the truss. The most common is the mortise and tenon joint, used in all post to beam, beam to beam or trimmer, compound rafter to king post or tie beam, bracket to post, rafter or sprocket to the trimmer. The second type is the half-lapped joint found in the compound rafter to queen-post connections. All the purlins and collars are notched. The rafters are bird's mouth cut and set on the purlins. There are no wooden pegs or wedges used for any of the joints while threaded rods are used in all post to collar or post to compound rafter, or compound rafter to collar connections. Iron straps are used for all the timber elements connected to the tie beam and posts to purlins. Three iron strips are used as brackets to connect the gable to the trusses.

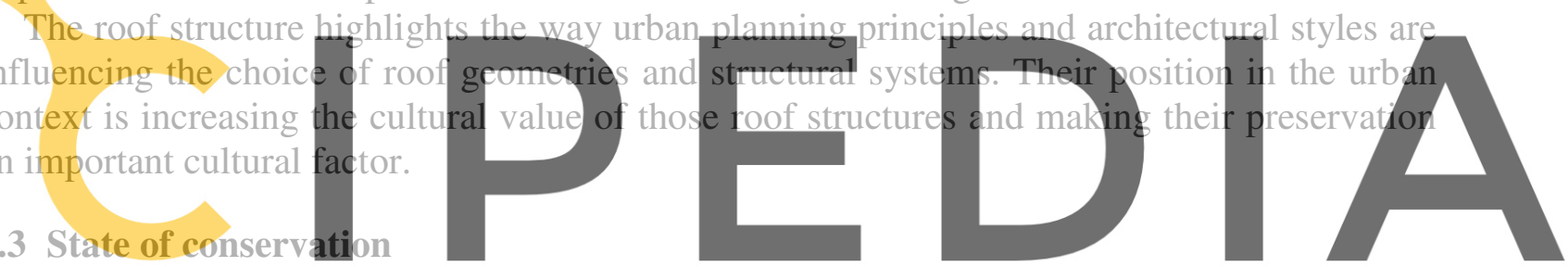

All visual examined pieces presented easily distinguishable growth-rings, the vessels are

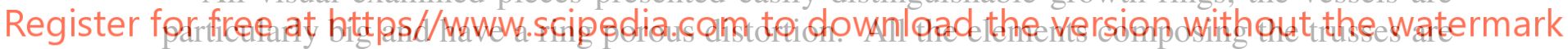
made from oak (Quercus sp.p.).

The timber roof is in an overall good state of conservation. No fungi or extent insect attack was spotted. Sparse decay of the trimmers was seen in the valley areas where they are in contact with the masonry. Traces of moisture induced damage are present, mainly in the area of the rafters and purlins but the leaking roof was constantly repaired. Additional damage caused by water infiltration in the ridge area led to the decay of the ridge purlins and the decorative exterior elements of the ridge.

No mechanical failures or big deflections of the timber elements have been detected.

\subsection{Symbolic analysis}

Previous studies performed on $18^{\text {th }}$ and $19^{\text {th }}$ century roof structures from Timisoara brought forward that craftsman used to define the position of main structural elements and joints based on various geometric principles and symbolic ratios. The studies brought forward that $18^{\text {th }}$ century and beginning of the $19^{\text {th }}$ century roof structure, build in the most active period of the craft-guilds were mainly defined by sacred ratios and dynamic ones $(\sqrt{2}, \sqrt{3}$ or $\sqrt{5})$ (Figure Ya) while end of the $19^{\text {th }}$ century, towards the fall of the guilds, roof structures were defined by 
dynamic and static ratios $(1 / 1,1 / 2,2 / 3)$. Ultimately, $20^{\text {th }}$ century roof structures tend to present a mix of various types of ratios, without clearly defining a geometrical pattern.

A geometrical analysis of the roof structure of the Löffler Palace was also performed in order to observe if this type of imposing roofs would also present any interest in complex geometries. The analysis showed that in the inferior part of the roof structure, dynamic ratios are predominantly used while the upper part is mainly defined by static ratios (Figure 6). Therefore, a $\sqrt{5}$ rectangle was used to define the distance the lower queen posts, compared to their height, while the position of the main queen posts is defined by a $\sqrt{2}$ rectangle. The same $\sqrt{2}$ rectangle was also observed in defining the distance between the inferior and intermediate collar ties compared to the distance between the main queen posts and the king post. Ultimately, the distance between the main queen posts is equal to the distance between the inferior and superior collar ties also highlighting the use of static ratios. Also, static and dynamic ratios were used to define the position of various joints, like the lower queen post and compound rafter or the compound rafter to upper collar ties joint. Still, no sacred ratios were identified.

The study revealed, as previously also observed during the geometrical analysis of the nearby placed Lloyd palace, a mix of different ratios. Still, compared to other $20^{\text {th }}$ century, less imposing roof structures, this case is still presenting a more coherent geometrical approach and a clear use of dynamic and static ratios to define the position of almost all the composing structural elements.
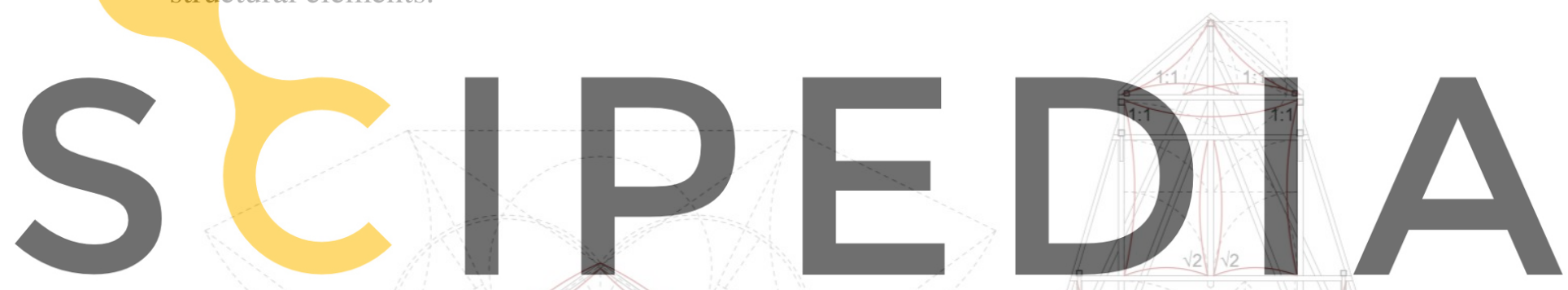

Register for free at https//www.scipedia.com to download the version without the watermark

a)

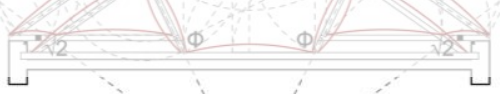

b)

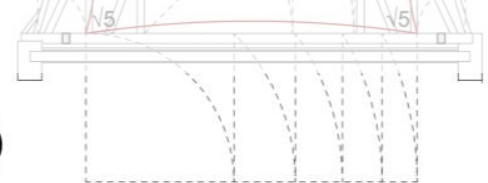

Figure 6: Analysed parameters (a) points where the displacements were measured; b) elements where the internal forces were analysed)

\subsection{Structural analysis}

Numerical simulations have been performed in the finite element simulation software SCIA engineer and were meant to highlight the importance of a proper investigation of a 20th century historical roof structure when addressing its structural behaviour. Therefore, two different scenarios were considered based on common practices in the structural assessment of historic roof structures. The first approach considered a more conservative approach but more timeefficient which ignored the possible cross-section loss of the timber elements and the traditionally crafted joints were modelled as hinged. The second approach was more related to the observations made on site, which led to a reduction of the cross-section of the timber 
element of $10 \%$, due to the rounded corners and the slight decay of the timber elements, while the semi-rigid behaviour of the timber joints was also considered. In this case, the axial stiffness of the joints was determined, based on their type, geometry and mechanical properties of the timber using the component method [21-23].

In order to be able to compare the results, the same loads were applied to the roof structure in both cases. The truss was loaded according to national standards with dead load, representing the self-weight of the timber elements and the weight of the roof envelope, life load and wind load. Since the roof pitch in the inferior part is of 74 degrees, the snow load was not considered in the load combination.

In order to identify the differences between the structural behaviour of the two cases, the horizontal $\left(\mathrm{U}_{\mathrm{x}}\right)$, vertical $\left(\mathrm{U}_{\mathrm{z}}\right)$ and total displacement $\left(\mathrm{U}_{\text {total }}\right)$ of a selection of six points were analysed. The points are placed in the middle of the structural elements which would suffer the most significant displacement caused by the applied loads: inferior rafters, superior rafters, tiebeam and the base of the king-post (Figure 7a). At the same time, the axial forces and bending moments recorded in the rafters, tie-beams and queen posts were analysed (Figure 7b).
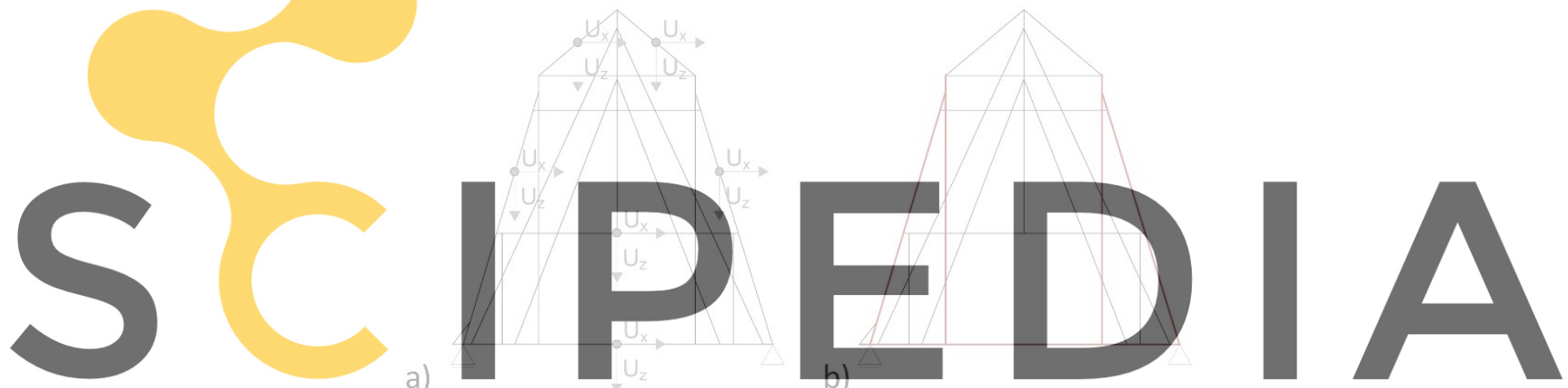

Figure 7: Analysed parameters (a) points where the displacements were measured; b) elements where the Register for free at https//www.scipedine.colnpreo dowanlload the version without the watermark

The displacement analysis is highlighting that the rafters are suffering the most significant displacement in both cases, up to about $10 \mathrm{~cm}$, considering the total displacement, while the tie-beam and base of the kingpost are only presenting a slight vertical and horizontal displacement of up to $6 \mathrm{~mm}$ (Table 1).

Table 1: Displacement comparison of the two considered cases

Conservative approach

After investigation

Comparative results

\begin{tabular}{cccccccccc} 
& $\mathrm{U}_{\mathrm{x}}[\mathrm{mm}]$ & $\mathrm{U}_{\mathrm{z}}[\mathrm{mm}]$ & $\mathrm{U}_{\text {total }}[\mathrm{mm}]$ & $\mathrm{U}_{\mathrm{x}}[\mathrm{mm}]$ & $\mathrm{U}_{\mathrm{z}}[\mathrm{mm}]$ & $\mathrm{U}_{\text {total }}[\mathrm{mm}]$ & $\mathrm{U}_{\mathrm{x}}[\%]$ & $\mathrm{U}_{\mathrm{z}}[\%]$ & $\mathrm{U}_{\text {total }}[\%]$ \\
\hline 1 & 81.3 & -26.4 & 85.4 & 121.9 & -40.4 & 128.4 & 35 & 35 & 35 \\
\hline 2 & -12.3 & -5.6 & 13.5 & -17.9 & -8.3 & 19.8 & 30 & 30 & 30 \\
\hline 3 & 65 & -79.2 & 102.5 & 98.7 & -120.4 & 155.7 & 35 & 35 & 35 \\
\hline 4 & -63.1 & -78 & 100.3 & -95.5 & -118.3 & 152 & 35 & 35 & 35 \\
\hline 5 & 5.7 & -2.5 & 6.2 & 9 & -4.1 & 9.9 & 35 & 40 & 35 \\
\hline 6 & 0.3 & -3.4 & 3.4 & 0.4 & -5 & 5 & 25 & 30 & 30
\end{tabular}


Still in all the cases when comparing the obtained results it becomes clear that the model with reduced cross-section elements and semi-rigid joints is presenting an up to $35 \%$ increase of the horizontal and total displacement, and an up to $40 \%$ increased of the vertical displacements. However, no significant variations of comparative results were observed for the considered analysis points.

The tie-beam is also presenting a slight change in the recorded internal forces. The axial forces increase with only up to $5 \%$, except for the tie-beam to second compound rafter, where an increase of $10 \%$ of the axial forces was recorded. Even for this element, the bending moments only vary slightly.

Ultimately, the internal forces on the queen posts were analysed. In this case, a clear difference between the obtained axial forces could be observed. Therefore, in the inferior part of the posts, up until the first collar ties, the axial forces increase with up to $5 \%$ for the second approach. Right above the first collar ties the axil forces increase with up to $25 \%$ and decrease with also $25 \%$ towards the second line of collar ties. Ultimately, at the top, the variations are insignificant. Compared to the previously analysed elements, in this case, the bending moments also present clear changes, with a $10 \%$ decrease at the base of the queen post and a $10 \%$ increase at the top.
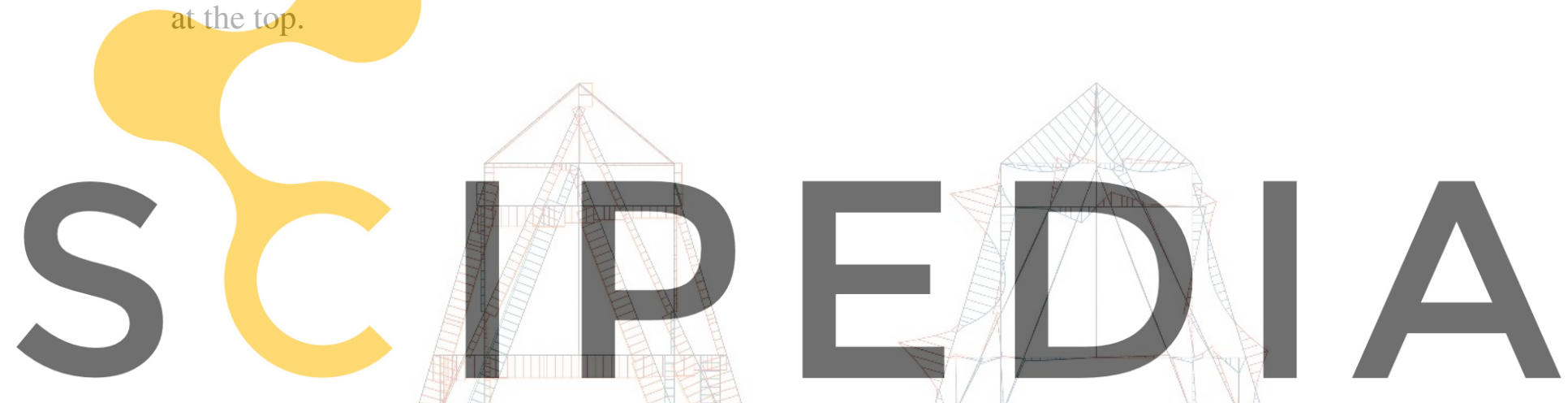

Register for free at https//www.scipedia.com to download the version without the watermark a)

Figure 8: Internal forces a) axial forces $(N)$; b) bending moments $\left(\mathrm{M}_{\mathrm{y}}\right)$

\section{CONCLUSIONS}

As already observed in previous studies the multidisciplinary analysis of the chosen $20^{\text {th }}$ century roof structure of the Löffler Palace brought forward that the preliminary assessment of a roof structure is a complex topic and that a series of context-related features also have to be taken into consideration.

The study shows that $20^{\text {th }}$ century roof structures, placed in representative places of the city are no longer simply meant to protect the building from meteorological factors but are also enhancing the importance of the building in its urban context. At the same time it can be observed that, despite being residential, the Löffler Palace is presenting an impressive roof which is not connected to its main function but rather to the urban context, the roof becoming one of the main aesthetical features of the building.

The surrounding urban area, the position of the building, related to public space and other 
neighbouring buildings and shape of the roof prove, therefore, to be features which connect a roof to its urban context and ultimately influence the choice of roof structure type and its structural complexity.

The study is also highlighting that even at the beginning of the $20^{\text {th }}$ century geometric principles were still used to link the height of the roof to the total height of the building, the position of main structural elements and joint, although, compared to $18^{\text {th }}$ and $19^{\text {th }}$ century roofs they were more simple.

Ultimately, the study is also highlighting the importance of a proper investigation of the geometry of the roof structure, the cross-section of the timber elements and their state of conservation on the structural behaviour of the roof. By using the on-site cross-section loss of the timber elements and the semi-rigid behaviour of the joints, results show a clear increase of the recorded displacements, slight changes of the axial forces and only little increase of the bending moments. Despite being more time consuming, this approach can prevent the misunderstanding of the historic timber roof structure which could lead to its partial or complete unnecessary replacement.

The study is therefore presenting a series of features which are important to be considered in order to be able to obtain a holistic and in-depth analysis of a historic timber roof structures. The proper understanding of the state of conservation and structural behaviour of the roof, is not only related to its immediate safety but also the buildings aesthetics, its role in the urban fabric and the way it is perceived from its surroundings.

The study represents a first step in the development of

methodologies by highl ghting a

step would the confirn

a comprehensive monitoring of

REFERENCES
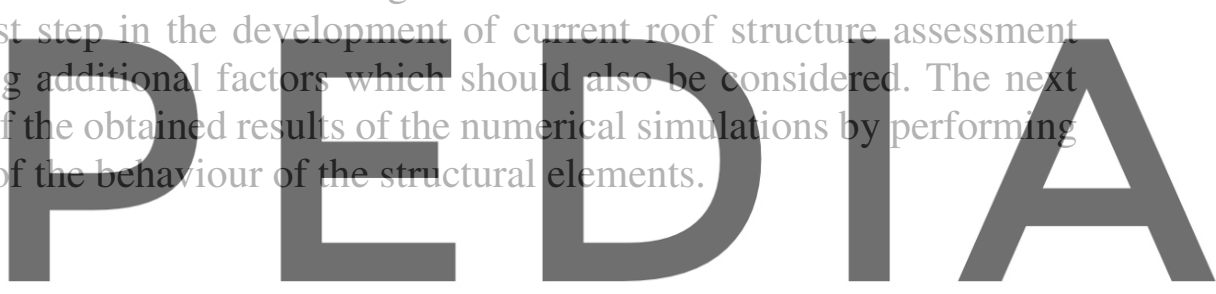

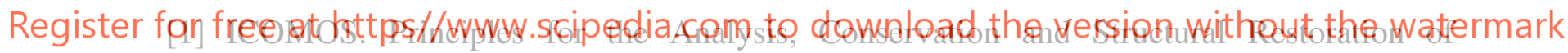
Architectural Heritage. Victoria Falls, Zimbabwe, (2003).

[2] Cruz, H., Yeomans, D., Tsakanika, E., Macchioni, N., Jorissen, A., Touza, M., Mannucci, M., Lourenço, P., Guidelines for On-Site Assessment of Historic Timber Structures. Int J Archit Herit (2015) 9(3):277-289.

[3] Riggio, M., D’Ayala, D., Parisi, M.A. and Tardini, C., Assessment of heritage timber structures: Review of standards, guidelines and procedures. J Cult Herit (2018) 31:220 235.

[4] Sousa, H.S., Machado, J.S., Branco, J.M. and Lourenço, P.B., Onsite assessment of structural timber members by means of hierarchical models and probabilistic methods. Constr Build Mater (2015) 101:1188-1196.

[5] Sousa, H.S., Branco, J.M., and Lourenço, P.B., A Holistic Methodology for Probabilistic Safety Assessment of Timber Elements Combining Onsite and Laboratory Data. Int J Archit Herit (2016) 10(5):526-538.

[6] Gocál, J., Krušinský, P., Capková, E. and Kekeliak, M., Geometric and static analysis of the historical truss in village Belá Dulice. (2014).

[7] Krušinský, P., Capková, E., Gocál, J. and Holešová, M., Geometric and static analysis of 
the historical trusses in roman catholic church of the Holy Kozma and Damian in the Abramová village. Civ Environ Eng (2015) 11(2):136-141.

[8] Krušinský, P., Gocál, J. and Capková, E., Static analysis of historical trusses. Wiadomości Konserw (2016) 47:120-127.

[9] Tannert, T., Dietsch, P., Bertolini-Cestari, C. and Kasal, B., COST Action FP1101 Assessment, Reinforcement and Monitoring of Timber Structures. In: Quenneville P (eds.). World Conference on Timber Engineering (WCTE).Curran Associates, Inc., Auckland, New Zealand, (2012), pp. 515-519.

[10] Kasal, B., Assessment, reinforcement and monitoring of timber structures-COST FP1101. Adv Mater Res (2013) 778:1037-1040.

[11]D’Ayala, D., Branco, J.M., Riggio, M., Harte, A., Kurz, J. and Descamps, T., Assessment, reinforcement and monitoring of timber structures: FPS Cost Action FP1101. In: Peña F (eds.). 9th International Conference on Structural Analysis of Historical Constructions (SAHC 2014).Springer, Mexico City, Mexico, (2014).

[12]Krušinský, P., Gocál, J. and Capková, E., Geometric and static analysis of the historical truss above presbytery of the Saint Peter of Alcantara monastery church in Okolicne. Procedia Eng (2015) 111:485-490.

[13] Krušinský, P., Capková, E. and Gocál, J., Comparison of Two Medieval Trusses from the Viewpoint of Geometric and Static Analysis. Adv Mater Res (2015) 1122:243-248.

[14] Gocál, J., Krušinský, P., Capková, E. and Kekeliak, M., Analysis of the historical truss in village Belá Dulice. Acta Sci Pol Form Circumiectus (2015) 14(1):57-73.

[15] Keller, A. and Mosoarca, M., A complex assessment of historic roof structures. In: Arun $\mathrm{G}$ (eds.). 4th International Conference on Structural Health Assessment of Timber Structures (SHATIS'17).(2017), pp. 157-168.

[16] Andreescu, I. and Keller, A., Complex features in assessing historic roof structures. In: Mazzolani F (eds.). 3rd International Conference on Protection Of Historical Constructions, PROHITECH'17. (2017).

[17] Mosoarca, M. and Keller, A., A complex assessment methodology and procedure for historic roof structures. Int J Archit Herit (2018) 12(4):578-598.

[18]Keller, A., Parisi, M.A., Tsakanika, E. and Mosoarca, M., Influence of historic roof structures on the seismic behaviour of masonry structures. Proc Inst Civ Eng - Struct Build (2019):1-27.

[19] Opris, M., Timisoara: small urban monography (in Romanian). Editura Tehnica, Bucarest, (1987).

[20] Geml, J., Old Timisoara (in Romanian). Editura Cosmopolitanart, Timisoara, Romania, (2016).

[21]Drdacky, M.F., Wald, F. and Mareš, J., Modelling Of Real Historic Timber Joints. Trans Built Environ (1999) 39:169-178.

[22] Descamps, T. and Lemlyn, P., Effects of the rotational, axial and transversal stiffness of the joints on the static response of old timber framings. In: Mazzolani F (eds.). Protection of Historical Buildings, PROHITECH 09. CRC Press, Taylor \& Francis Group, Rome, Itlay, (2009), pp. 291-286.

[23] Branco, J.M. and Descamps, T., Analysis and strengthening of carpentry joints. Constr Build Mater (2015) 97:34-47. 